\title{
BEVEZETŐ GONDOLATOK A VEZETÉSTUDOMÁNY CÍMÜ FOLYÓIRAT HÁLÓZATI TÉMAKÖRBEN MEGJELENŐ KÜLÖNSZÁMÁHOZ
}

$\mathrm{E}_{\mathrm{s} \text { ses }}^{\mathrm{k}}$ különszám tematikus fókuszát talán nem is lenne szükséges indokolni, hiszen a gazdasági jelenségek hálózatos megközelítésen nyugvó elemzésének térnyerése az elmúlt évtized egyik legmarkánsabb jelensége. Mint a különszám szerkesztője mégis szeretném megemlíteni itt a Budapesti Corvinus Egyetem által elnyert pályázatot, mely 'Intelligens szakosodást szolgáló intézményi fejlesztések a Budapesti Corvinus Egyetem székesfehérvári Campusán' (EFOP-3.6.116) címet viseli. Egy, a kutatásfejlesztést, kutatói utánpótlást támogató pályázatról van szó, melybe száznál több fiatal, és őket támogató tapasztalt kutató kapcsolódott már be. A pályázathoz tartozó kutatások igen sokszínűek, de közös bennük, hogy a gazdasági/üzleti hálózat, mint átfogó témakör valamelyik aspektusához kapcsolódnak.

A különszám felhívásakor alapvetően számítottunk az itt kutató kollégák munkáira, de nyitottak voltunk. A hálózat tág témaköréhez kapcsolódás volt a meghatározó szempont. A gazdasági/üzleti hálózatok témaköre pedig igen széles. Vállalati példák sokasága mutatja, hogy valami megváltozott a gazdasági jelenségek világában, azok a vállalatok/szervezetek tünnek versenyképesebbnek, amelyek értik üzleti hálózatuk dinamikáját, és azt proaktív módon befolyásolni is képesek. Igaz ez nem csak az internetalapú, digitális alapokon nyugvó, ,született” hálózati iparágakra, de szinte minden más ágazatra is.

Első pillantásra egyszerü e hálózat megragadása, hiszen mint minden hálózat, az üzleti hálózat is csomópontok és a közöttük lévő élek összetartozó halmazaként értelmezhető. Esetünkben pedig ezek a csomópontok gazdasági aktorok - elsősorban vállalatok -, míg a közöttük lévő élek az üzleti kapcsolatok. A tudományos igényü és a gyakorlat számára is releváns kutatási eredmények szempontjából ugyanakkor a gazdaság hálózati alapokon történő elemzése komoly elméleti és módszertani kihívásokkal jár együtt. Igaz ez már akkor is, ha nem összetett hálózati struktúrák szintjén kívánunk elemzéseket végezni - mint például az ellátási láncok (Lazzarini et al., 2001), vagy globális értékláncok (Sturgeon et al., 2008) -, hanem a hálózat alapegységét, magát az üzleti kapcsolatot (Snehota \& Håkansson, 1995) akarjuk mélyebben megérteni. A fogalmi kihívások egy része az elméleti háttér sokszínűségéből adódik. A gráfelméleti alapokon nyugvó hálózati elemzések (Barabási, 2016) mellett a társadalmi kapcsolatoknak és azok szerkezetének elemzésével (social network analysis) foglalkozó szakirodalom (Skott, 1988), vagy a szervezetközi marketingből kifejlődő üzleti hálózatok megközelítés (Håkansson \& Ford, 2002) egyaránt releváns tudományos eredményekhez vezetett már a gazdasági/üzleti hálózatok esetében.

A kapcsolati jelenségek kutatása módszertani kihívásokat is támaszt. Egyetlen üzleti kapcsolat elemzése bár fontos, de szükségszerüen korlátozott tudáshoz vezet, hiszen például nem alkalmas a hálózat dinamikájában megfigyelhető jelenségek megértésére. Ehhez minimálisan három szereplő és a közöttük létrejövő kapcsolatrendszer szükséges. Ezt az elemzési egységet kapcsolati triádként is szokás nevezni, s az elmúlt években a tudományos kutatás egyre jelentősebb elemzési egységévé vált (Choi \& Wu, 2009). A hálózat fenti alapvető elemzési egységei ráadásul nem csak szervezeti szinten értelmezhetők, de fontosak a szervezetet alkotó egyének szintjén is, legyen szó akár döntéshozókról, akár azok végrehajtóiról.

A fentiekből fakadóan ez a különszám is igen sokszínű. Az egyes tanulmányok természetesen különböznek a konkrét kutatási kérdésekben, de eltérőek a választott hálózati elemzési szint és az alkalmazott módszertan tekintetében

1. táblázat A különszámban megjelenő cikkek néhány kiemelt jellemzője

\begin{tabular}{|l|l|l|l|}
\hline \multicolumn{1}{|c|}{ Szerzö(k) } & \multicolumn{1}{|c|}{ Vizsgált kérdéskör } & \multicolumn{1}{c|}{ Hálózati elemzési szint } & \multicolumn{1}{c|}{ Alkalmazott módszertan } \\
\hline $\begin{array}{l}\text { Bauer András, Mitev Ariel és } \\
\text { Gáti Mirkó }\end{array}$ & $\begin{array}{l}\text { Kommunikációs csatornák hatása } \\
\text { a bizalomra, mint kiemelt kapcsolati } \\
\text { jellemzöre }\end{array}$ & $\begin{array}{l}\text { Üzleti kapcsolat, mint a hálózat } \\
\text { alapegysége }\end{array}$ & $\begin{array}{l}\text { Kismintás kvantitatív } \\
\text { elemzés, PLS-SEM modell) }\end{array}$ \\
\hline Baksa Máté & Negatív kapcsolatok & Szervezeti hálózatok & Szakirodalmi összefoglaló \\
\hline $\begin{array}{l}\text { Csutora Mária és Harangozó } \\
\text { Gábor }\end{array}$ & $\begin{array}{l}\text { Széndioxid-mérés ellátási láncok } \\
\text { szintjén }\end{array}$ & $\begin{array}{l}\text { A széndioxid-kibocsátás } \\
\text { mése ellátásilánc/hálózat } \\
\text { szintjén }\end{array}$ & $\begin{array}{l}\text { A vizsgált vállalatok } \\
\text { nyilvánosan elérhető anyagai } \\
\text { alapján kvalitatív kutatás }\end{array}$ \\
\hline Halmosi Péter & $\begin{array}{l}\text { Ipar 4.0 lehetőségei, kihívásai } \\
\text { technológiaorientált és } \\
\text { hagyományos kisvállalatok számára }\end{array}$ & $\begin{array}{l}\text { Információtechnológia-alapú } \\
\text { összetett hálózatok }\end{array}$ & $\begin{array}{l}\text { Kérdőíves felmérés, } \\
\text { leíró elemzés }\end{array}$ \\
\hline Huszák Loretta & $\begin{array}{l}\text { Egyetemi/kutatóintézeti tudás- és } \\
\text { technológiatranszfer }\end{array}$ & $\begin{array}{l}\text { Egy kiemelt ágazat tágan } \\
\text { értelmezett hálózata }\end{array}$ & Esettanulmányok \\
\hline Molnár Gábor Tamás & $\begin{array}{l}\text { Vállalkozói szerveződések szerepe } \\
\text { a szerződéses kapcsolatok } \\
\text { támogatásában }\end{array}$ & $\begin{array}{l}\text { Egy kiemelt ágazat tágan } \\
\text { értelmezett hálózata }\end{array}$ & Esettanulmány \\
\hline Édes Balázs & $\begin{array}{l}\text { Közösségi közlekedés } \\
\text { ügyfélélmény-alapú elemzése }\end{array}$ & $\begin{array}{l}\text { Közekedési hálózatok összetett } \\
\text { úzleti hálózatként való értelmezése }\end{array}$ & Esettanulmány \\
\hline
\end{tabular}


is. A különszám felépítését a hálózati jelenségek vizsgálata során alkalmazott lehetséges elemzési szintek mentén tagoltuk, alapvetően az egyszerübb felöl az összetettebb szintek felé haladva. A cikkek döntő többsége összetett hálózatokat vizsgál. Egyetlen munka (Bauer et al.) fókuszál az üzleti hálózatok alapegységére, magára a kapcsolatra. Az összetett hálózatokat vizsgáló tanulmányok között találunk olyat, mely a szervezeten belüli személyközi kapcsolati hálót helyezi a vizsgálódás középpontjába (Baksa), a megjelenő tanulmányok döntö többsége ugyanakkor a szervezetközi hálózatokat kutatja. A hálózat talán leginkább kutatott alrendszere maga az ellátási lánc, ezen a szinten végzi elemzését Csutora és Harangozó. Halmosi munkája az Ipar 4.0 kontextusában a szervezetközi kapcsolatok teljes értéklánc mentén történő integrációjának megközelítését alkalmazza. Huszák és Molnár tanulmányaiban közös, hogy egy-egy ágazat mentén szerveződő hálózatok szintjén vizsgálódnak. Sajátos elemzési megközelítést alkalmaz Édes cikke, mely infrastrukturális, müszaki háttere miatt hagyományosan is hálózatosnak tekintett egyes közlekedési ágazatok összekapcsolódásával létrejövő elemzési szinten - mondhatjuk a hálózatok hálózatának szintjén - végzi elemzését.

A különszám az alkalmazott módszertanban is sokszínű, egy szakirodalmi összefoglaló, két kérdőíves felmérésen nyugvó kvantitatív elemzés mellett többnyire az esettanulmány feltáró elemzési eszközét alkalmazza.

\section{A cikkek rövid ismertetése}

Bauer András - Mitev Ariel - Gáti Mirkó: Kommunikációs csatornák és az innovációs magatartás hatása a bizalomra, valamint a vevőkapcsolati teljesítményre a személyes értékesítésben

A cikk az üzleti hálózatok alapvető egységét, a diadikus kapcsolatokat vizsgálja. Központi kutatási kérdése, hogy az értékesítők által használt offline és online kommunikációs csatornák, valamint innovációs magatartásuk milyen hatással van a bizalomra és a vevőmegtartásra (Baraldi \& Nadin, 2006). A szervezeti határokon müködö, így a szervezeteket összekötő munkatársaknak meghatározó szerepük van a hálózatok kialakulásában és működésének minőségében. Ezek közé az ún. boundary spanning munkatársak közé tartoznak az értékesítők, akik kommunikációja ma már nem csak a hagyományos, offline, de az online térben is egyre intenzívebb, és közvetlenül hatással lehet kiemelt kapcsolati jellemzőkre, így például a kapcsolati bizalomra.

A szerzők egy kismintás kérdőíves felmérés adatai alapján, PLS-SEM modell segítségével vizsgálják az értékesítők e két kommunikációs típusának hatását a bizalomra és a vevőkapcsolat minőségére (elemzésükbe moderáló tényezőként bevonják az értékesítők innovációs magatartását is). A kutatási eredmények azt mutatják, hogy az offline és az online kommunikáció egyaránt pozitív hatással van a bizalomra, vagyis a minőségi kapcsolattartás - függetlenül annak módjától - a bizalomépítés alapját jelenti.

Baksa Máté: Negatív kapcsolatok a szervezeti hálózatokban - meghatározások, módszerek és mércék

A cikk középpontjában a negatív kapcsolatok állnak. E kapcsolati típus kutatása Magyarországon sem előzmény nélküli. Csaba és Pál (2010) például középiskolákban vizsgálta a negatív kapcsolatok alakulását. Ezt a kutatási területet később Pál doktori disszertációjában (2016) még mélyebben elemezte. Rácz (2014) pedig az ún. egóközpontú kapcsolati hálók mentén tárgyalja a jelenséget. Ennek ellenére az is megállapítható, hogy a jelenség szervezeti hálózat kontextusában történő tárgyalása a hazai szakirodalomban ritka. Ezért is bír relevanciával ez az alapvetően a nemzetközi szakirodalom feldolgozására építő, rendszerező munka.

A szerző elsőként a negatív kapcsolatok értelmezési kérdéseit tárgyalja. Ez szükségszerűen diadikus megközelítést igényel, hiszen két, valamilyen szempontból kapcsolatban álló egyén közötti jelenségként értelmezhetö. Ugyanakkor az értelmezés során a kapcsolatot alkotó egyének személyes jellemzőinek (pl. kognitív ítéletek, negatív érzések és magatartási szándékok) kitüntetett jelentőségük van, így az értelmezés során az egyéni és a diadikus vizsgálati szintek szorosan kapcsolódnak egymáshoz. Az értelmezési kérdéseket követően a cikk a negatív kapcsolatok szervezeti hálózatra gyakorolt hatása kapcsán elért eddigi legfontosabb kutatási eredményeket foglalj össze. Itt már a hálózat összetettebb szintjén is zajlik az elemzés (pl. triád). A kutatási eredmények rámutatnak arra, hogy a negatív kapcsolatok több esetben másként müködnek, mint a pozitív kapcsolatok. Ez a különbség már a kutatások adatfelvételi lépésénél figyelmet igényel, mint ahogyan az adatelemzési és értelmezési sajátosságokra is figyelmet kell fordítaniuk a kutatóknak, hiszen hálózatelmélet ismert mutatószámai sokszor csak módosításokkal alkalmazhatók. A szervezetközi kapcsolatok kutatásához képest sajátossága ugyanakkor ennek a kutatási témának az az etikai dilemma, mely a negatív kapcsolatok vizsgálatakor élesen felmerül. Hogyan kezeljük és használjuk fel a kutatás során a megszerzett, egyénekkel kapcsolatos adatokat? Hiszen igen szenzitív információk kezeléséröl van szó, mely nagy körültekintést kíván meg a kutatóktól.

Csutora Mária - Harangozó Gábor: Széndioxid-elszámolás a hálózati gazdaságban

A tanulmány fókuszát a vállalati szintü üvegházhatású gáz, illetve ezen belül a széndioxid-elszámolás módszertani és gyakorlati kérdései képezik, de hálózati kontextusban, hiszen a szerzők a vállalati határokon átnyúló ellátási láncok szintjén végzik elemzésüket. Munkájuk egyrészt rendszerező jellegü áttekintést ad a vállalati széndioxidelszámolás kialakulásáról; másrészt 16 vállalat nyilvánosan elérhető anyagainak elemzésével megvizsgálja a vállalati határokon túlnyúló kibocsátások elszámolásának hazai gyakorlatát. Az ún. Scope 3-ba tartozó kibocsátások (WBCSD/WRI, 2011) összefüggésben vannak a vállalat tevékenységével, de olyan forrásokból származnak, amelyeket a vállalat sem pénzügyi, sem pedig müködési kontroll alatt nem tart, tehát a vállalat ellátási láncában, tágabban értelmezve üzleti hálózatában vele együttmüködő partnerekhez köthetök.

A hazai nagyvállalatok széndioxid-elszámolási gyakorlatának ún. Scope 3 eszközökkel történő vizsgálatának célja, hogy feltérképezzék, ezek a vállalatok mennyire törekednek el a vállalaton túlnyúló hatások számszerűsítésére, illetve rendelkeznek-e ezek csökkentésre vonatkozó 
stratégiával. Vizsgálatuk rámutat, hogy a Magyarországon tevékenykedő vállalatok már komoly figyelmet fordítanak a vállalati szintű széndioxid-elszámolásra, a közvetlen (Scope 1) és a vásárolt energiához kapcsolódó (Scope 2) kibocsátásaikat nagyrészt számszerüsítik, de az ellátási lánc további részeinél megjelenő kibocsátások elszámolása még gyerekcipőben jár.

Halmosi Péter: A technológiaorientált start-up cégek lehetőségei és korlátai az Ipar 4.0 korszakában - kérdőíves felmérés alapján

Az Ipar 4.0 lényege, hogy lehetővé teszi a vállalatok teljes értéklánc mentén történő integrálását (Heynitz et al., 2016; Baldassarre et al., 2017). Ez azt jelenti, hogy a nagy mennyiségü adatok összegyüjtése és feldolgozása révén olyan hálózatok jönnek létre, melyek alapvetően változtatják meg az eddig domináns üzleti modelleket. A hálózatoknak ez az információtechnológiai alapon nyugvó kiteljesedése komoly üzleti lehetőségeket tartalmaz. A cikk egy friss hazai felmérés tükrében vizsgálja, hogy miként gondolkodnak az Ipar 4.0 által biztosított elönyökről, vagy éppen gátló tényezőkről a hazai a technológiaorientált más néven a korai fázisú - start-up cégek, és a hagyományos hazai kisvállalkozások. A felmérés vizsgálta az Ipar 4.0 bevezetésének akadályait, azok várható hatásait, az ezzel kapcsolatos növekedési stratégiákat, a kapcsolódó menedzsmenttevékenységeket, -képességeket.

Mindkét vállalatcsoport az Ipar 4.0 bevezetésének legfőbb akadályát a tőkeigényes beruházásokban látja. Jelentős különbségek mutathatók ki ugyanakkor a bevezetést befolyásoló más tényezőkben. A korai fázisú cégek tulajdonosai szerint az Ipar 4.0 képes lesz rávilágítani a szervezetek gyenge pontjaira. A hagyományos kisvállalkozások megítélése szerint probléma, hogy nem áll rendelkezésre a változások menedzseléséhez szükséges tudás. Az üzleti modellek megváltozásának jelentőségét mindkét vállalatcsoport reálisnak és fontosnak tartja. A korai fázisú vállalkozások növekedési stratégiájában meghatározó szerepe van a termékfejlesztésnek és a földrajzi terjeszkedésnek. A siker alapvető feltétele szerintük a hálózatban való gondolkodás képessége. E hálózatok számos összekapcsolódó vállalatot ölelnek fel, melynek hatékony kezelése fontos vezetői kompetenciaként azonosítható.

Huszák Loretta: Nyomokban tudástranszfert tartalmaz - Tudásalapú hálózatosodás Fejér megyében. A kutatóintézményi oldal

A tanulmány a tudás- és technológiatranszfer, azaz a tudásalapú hálózatosodás kérdéskörét vizsgálja. A fókuszban lévő hálózat két alapvető szereplő típusát a felsőoktatási/tudományos szervezetek és a vállalatok jelentik, a vizsgálat a közöttük zajló tudásmegosztás, tudásteremtés és -hasznosítás intézményi feltételrendszerét és eredményességét elemzi. A témakör gazdag szakirodalmához kapcsolódóan (Siegel et al., 2003; Brescia et al., 2016) egyrészt rendszerezetten bemutatja az egyetemi/kutatóhelyi tudáshasznosítás hazai jogszabályi lehetőségeinek és ösztönzőrendszerének elmúlt másfél évtizedben bekövetkezett változásait. Másrészt, ennek tükrében kvalitatív kutatásmódszertant alkalmazva vizsgálja a Fejér megyében aktív hat oktatási/kutatási intézmény ezirányú tevé- kenységeinek szervezeti megoldásait, azok időbeli változását. Végül, de nem utolsó sorban az eKutatás adatbázisa felhasználásával ismerteti a szerző a vizsgált oktató és kutatóintézetek ezirányú tevékenységének eredményességét.

A vizsgált intézmények mindegyikénél felvállalt tevékenység az innováció és technológiatranszfer, a vizsgált felsőoktatási intézmények ugyanakkor még meglehetősen távol vannak a vállalkozó egyetem/föiskola modelljétől. A tudásalapú hálózatosodás egyértelműen jelen van a térségben, de a létrejövő kutatóintézet-vállalat kapcsolatrendszerekben még mindig a képzés területén megjelenő együttmüködések a meghatározóak. Ezen belül is intézményesült formában, szerződésekkel alátámasztva elsősorban a duális képzés a leggyakoribb.

Molnár Gábor Tamás: A vállalkozói szerveződések szerepe a szerződéses kapcsolatok támogatásában - egy magyar ágazat tanulságai

A tanulmány az intézményi közgazdaságtan alapján hangsúlyozza, hogy a gazdasági szereplők hitelességét különféle „szerződéskikényszerítő intézmények” teremthetik meg: olyan társadalmi játékszabályok, amelyek szankcionálják az ígéretszegést (Williamson, 1979). A szerző egy ilyen kiemelt intézménytípus, az ágazati szakmai szerveződések szempontjából vizsgálja a kérdéskört. Konkrétan a vetőmagtermelés és -kereskedelem szempontjából vizsgálja, miként támogatják az ágazati-szakmai szerveződések a vállalkozások közötti szerződéses kapcsolatokat. A vállalkozói szerveződések a szerződéskikényszerítés irányítási struktúrájába többféleképpen illeszkedhetnek. Egyrészt az állami intézmények hiányosságai esetén a vállalkozói szerveződések vehetik át a szerepüket a spontán rend kiegészítésében. Abban az esetben is fontos elemei lehetnek ezek az intézmények az átfogó irányítási struktúrának, ha a magán és az állami intézmények alapvetően müködnek, de kiegészítésre szorulnak. Meg kell említeni azt a sajátos, posztszocialista helyzetet is, amikor a vállalkozói szerveződések állami kapcsolati hálóra épülnek rá, helyettesítve a magánrendet.

A kiválasztott ágazat esettanulmány arra utal, hogy a vállalkozói szerveződések szerződéskikényszerítő funkciói elsősorban a rövid távú, piaci jellegű kapcsolatokban fontos. Jelentős a vállalkozói szerveződések információközvetítő funkciója, mely támogathatja a reputációt. A piaci közvetítők jelenléte ugyanakkor kétféleképpen befolyásolja a vállalkozói szerveződések jelentőségét: egyrészt növelheti azt, amennyiben a közvetítők kapcsolataik kiépítésében hagyatkoznak a szerveződések funkcióira. Másrészt csökkentheti is e szerveződések fontosságát, amenynyiben a közvetítők kiterjesztik a szerveződések funkcióit kapcsolati és hírnévalapú szankciókkal helyettesítő irányítási struktúra terét. Továbbá az állami rend mechanizmusainak fontossága növelheti a vállalkozói szerveződésekre való hagyatkozást, mivel a szerveződések csatornázzák be a vállalkozói közösségek szempontjait a kormányzathoz, megalapozva az állami mechanizmusok müködését.

Édes Balázs: Egy hálózatos iparág élő hálózatok nélkül - Hogyan ragadt a magyar közösségi közlekedési rendszer az előző évszázadban, és miként lehetne pótolni az átaludt évtizedeket? 
A szerző a közösségi közlekedési rendszert vizsgálja. Alapproblémája az egyéni és a közösségi közlekedési módok közötti választás. A közösségi közlekedés középpontjában a vasút és a kapcsolódó közlekedési ágak (távolsági és helyi buszközlekedés) áll, ahol a választást alapvetően befolyásolja az ügyfélélmény (Pine \& Gilmore, 1998), mely megkerülhetetlenné teszi, hogy ezeket a kapcsolódó közlekedési ágakat integrált hálózatként, a szolgáltatásmarketing megközelítésében vizsgáljuk. A cikk tehát több szempontból is kapcsolódik a gazdasági hálózatok témájához. Technológiai szempontból, hiszen a hagyományos, az infrastruktúra, technológia alapján is hálózatos iparágak állnak az elemzés középpontjában. Ráadásul ezek összekapcsolódásaként létrejövő kiterjesztett közlekedési hálózatok (hálózatok hálózata) jelentik az elemzés egységét, hiszen csak az egyes közlekedési ágak hálózatainak integrációjával nyújtható olyan versenyképes ügyfélélmény, mely képes lenne erősíteni a közösségi közlekedést.

A témakör ügyfélélmény-alapú vizsgálata a nemzetközi tudományos életben sem gyakori. A tanulmány az üzleti tudományok eszköztárával elemzi a kérdéskört. Folyamatszemléletben, egy ún. customer journey map (azaz fogyasztói utazás térkép; Houston, 2018) feltérképezésével azonosítja a kiemelt szolgáltatáselemeket, és azok mentén az érintett közlekedési ágak kapcsolódási pontjait. A vevői élmény szempontjából ezeknek a pontoknak kiemelt jelentőségük van, hiszen azok tudatos menedzsmentje ( $\mathrm{pl}$. a menetrendek összehangolása) közvetlenül hat az utazó ügyfél által fontosnak tartott minőségi tényezők megítélésére. Az elméleti kapcsolatrendszer felvázolásán túl a szerző a hazai vasúti közlekedést kiindulópontként kezelve értékelö elemzést is ad a hazai közösségi közlekedés ügyfélorientált, élményalapú szolgáltatásának állapotáról.

\section{Dr. Gelei Andrea} egyetemi tanár Budapest Corvinus Egyetem

\section{Felhasznált irodalom:}

Baldassarre, F., Ricciardi, F., \& Campo, R. (2017). The advent of Industry 4.0 in manufacturing industry: Literature review and growth. Opportunities. https://hrcak. srce.hr/file/276313. Letöltve: 2019. március 6.

Barabási, A. L. (2016). Network science. Cambridge, UK: Cambridge University Press.

Baraldi, E. \& Nadin, G. (2006). The Challenges in digitalising business relationships. The construction of an IT Infrastructure for a textile-related business network. Technovation, 26 (10), 1111-1126.

Brescia, F., Colombo, G., \& Landoni, P. (2016). Organizational structures of knowledge transfer offices: An analysis of the world's top-ranked universities. The Journal of Technology Transfer, 41(1), 132-151.

Choi, T. Y., \& Wu, Z. (2009). Triads in supply networks: Theorizing buyer-supplier-supplier relationships. Journal of Supply Chain Management, 45(1), 8-25.

Csaba Z. L. \& Pál J. (2010). A negatív kapcsolatok alakulása és hatása: elméleti áttekintés és empirikus tesztelés két középiskolai osztályban. Szociológiai Szemle, 20(3), 4-33.

Heynitz, H.v., Bremicker, M., Amadori, D. M., \& Reschke, K. (2016). The factory of the future. KPMG AG, Németország. https:/assets.kpmg.com/content/dam/ kpmg/es/pdf/2017/06/the-factory-of-the-future.pdf Letöltve: 2019. március 5.

Håkansson, H., \& Ford, D. (2002). How should companies interact in business networks?. Journal of Business Research, 55(2), 133-139.

Lazzarini, S., Chaddad, F., \& Cook, M. (2001). Integrating supply chain and network analyses: the study of netchains. Journal on Chain and Network Science, 1(1), 7-22.

Pál J. (2016). Státusz és negatív kapcsolatok: Egy longitudinális hálózatelemzés középiskolások körében (PhDdisszertáció), BCE Szociológia Doktori Iskola, Budapest, Magyarország.

Pine, B.J. \& Gilmore, J. H. (1998). Welcome to the experience economy. Harvard Business Review, 76, 97-105.

Rácz A. (2014). Egóközpontú kapcsolati hálók mérési módszerei. Magyar Pszichológiai Szemle, 69(3/6), 567-593.

Scott, J. (1988). Social network analysis. Sociology, 22(1), 109-127.

Siegel, D. S., Waldman, D. A., Atwater, L. E., \& Link, A. N. (2003). Commercial knowledge transfers from universities to firms: improving the effectiveness of university-industry collaboration. The Journal of High Technology Management Research, 14(1), 111-133.

Snehota, I., \& Håkansson, H. (Eds.). (1995). Developing relationships in business networks. London: Routledge.

Sturgeon, T., Van Biesebroeck, J., \& Gereffi, G. (2008). Value chains, networks and clusters: reframing the global automotive industry. Journal of Economic Geography, 8(3), 297-321.

WBCSD/WRI (2011). The Greenhouse Gas Protocol Corporate Value Chain (Scope 3) Accounting and Reporting Standard. Supplement to the GHG Protocol Corporate Accounting and Reporting Standard. World Business Council for Sustainable Development and World Resources Institute. Geneva, pp. 152.

Williamson, O. E. (1979). Transaction-Cost Economics: The Governance of Contractual Relations. The Journal of Law and Economics, 22(2), 233-261.

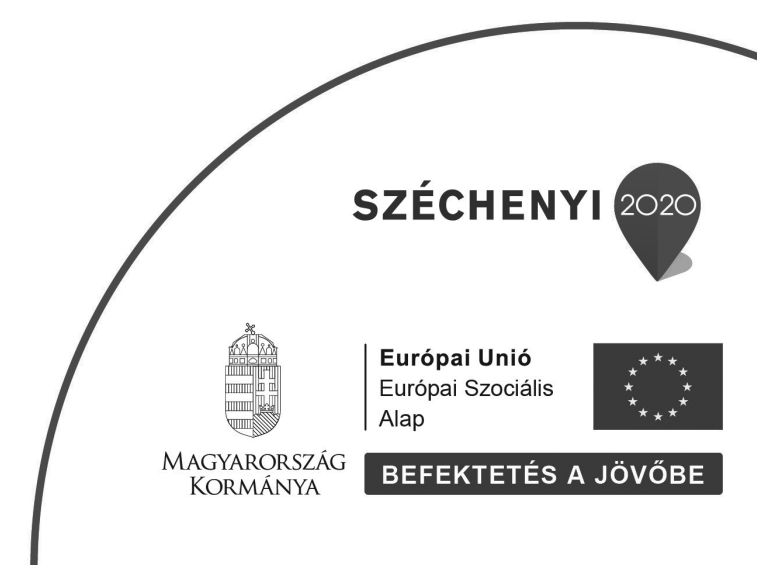

